Sains Malaysiana 49(1)(2020): 85-92

http://dx.doi.org/10.17576/jsm-2020-4901-10

\title{
Analysis of Free Oligosaccharides (fOS) from Wild-Type Saccharomyces cerevisiae (Baker's Yeast) using Two Different Extraction Methods
}

(Analisis Oligosakarida Bebas (fOS) daripada Saccharomyces cerevisiae (Yis Baker) Jenis Liar menggunakan Dua Kaedah Pengekstrakan Berbeza)

\author{
Iqbal Jalaludin, Amirul Husna Sudin, Dharshini Elangovan, Hussein M. Al-Bajalan, Nur \\ Maisarah Sarizan, Noor liana Mat Yajit, Kamalrul Azlan Azizan, Abdul Munir Abdul Murad, \\ Farah Diba Abu Bakar, Dominic S. Alonzi \& Mukram Mohamad Mackeen*
}

\begin{abstract}
The glycomic profiles of free oligosaccharides (fOS) derived from misfolded N- and O-linked glycoproteins and lipidlinked oligosaccharides are important molecular signatures in various biological processes and serve as a readout of functional properties such as glycosidase inhibition. Several glycan extraction methods are available based on different sorbent chemistries that may influence the analytical profiles obtained. However, there is limited availability of studies comparing the effects of sorbent chemistries on glycan profiles. Therefore, in our study, the fOS profiles from wild-type Saccharomyces cerevisiae (Baker's yeast) extracted using two common methods namely mixed-bed ion-exchange (MBIE) $\left[A G 50 \mathrm{~W}-\mathrm{X} 12\left(\mathrm{H}^{+}\right)\right.$and $\left.\mathrm{AG}-\mathrm{X} 8(\mathrm{Cl})\right]$ and reversed-phase (C18) sorbents were compared using total carbohydrate (phenol sulfuric acid) and total protein (bicinchoninic acid, BCA) assays, thin-layer chromatography (TLC) and highperformance liquid chromatography-evaporative light scattering detector (HPLC-ELSD) analyses. MBIE extraction contained higher oligosaccharide and protein $(0.26 \mathrm{mg} / \mathrm{mL}$ and $1.8 \mathrm{mg} / \mathrm{mL})$ content than C18 extraction $(0.11 \mathrm{mg} / \mathrm{mL}$ and $0.2 \mathrm{mg} / \mathrm{mL}$ ). TLC analysis (butanol: ethanol: water = 6:3:1 and 5:4:1) showed the presence of fOS in both the MBIE and $C 18$ extracts based on the detection of orcinol active (UV-inactive) spots. Similar peaks were present in the HPLCELSD chromatograms for both extractions methods with MBIE showing higher abundance. Glycan unit (GU) analysis of the dextran standard using HPLC-ELSD showed that the largest possible oligosaccharide structures detected were only di/trisaccharides. Based on all these results, MBIE extraction is a more suitable carbohydrate extraction technique compared to C18 extraction for subsequent profiling and functional studies of fOS.
\end{abstract}

Keywords: Free oligosaccharides (fOS); glycans; HPLC-ELSD; Saccharomyces cerevisiae; TLC

\section{ABSTRAK}

Profil glikomik oligosakarida bebas (fOS) yang diterbit daripada glikoprotein $N$ - dan O- yang tersalah lipat serta oligosakarida terpaut-lipid (LLO) adalah penanda molekul penting dalam pelbagai proses biologi dan berfungsi sebagai bacaan terhadap sifat berfungsi seperti perencatan glikosidase. Beberapa kaedah pengekstrakan glikan boleh didapati berdasarkan pelbagai kimia bahan erap yang berbeza yang mungkin mempengaruhi profil analitik. Walau bagaimanapun, kajian terhadap perbandingan kesan kimia bahan erap terhadap profil glikan adalah terhad. Oleh itu, dalam kajian ini profil fOS daripada Saccharomyces cerevisiae (yis Baker) jenis liar diekstrak menggunakan dua kaedah yang digunakan secara meluas iaitu bahan erap dan pertukaran ion lapisan-campuran (MBIE) [AG50W-X12 ( $\left.\mathrm{H}^{+}\right)$dan $\mathrm{AG}-\mathrm{X}-\mathrm{X} 8(\mathrm{Cl})$ dan fasa berbalik (C18) dibandingkan dengan jumlah karbohidrat (asid fenol sulfurik) dan jumlah protein (asid bisikoninik, $B C A)$, kromatografi lapisan nipis (TLC) dan kromatografi cecair berprestasi tinggi-penyejatan penyerakan cahaya (HPLC-ELSD). Pengekstrakan MBIE mengandungi kandungan oligosakarida dan protein yang lebih tinggi iaitu (0.26 $\mathrm{mg} / \mathrm{mL}$ dan $1.8 \mathrm{mg} / \mathrm{mL}$ ) berbanding dengan pengekstrakan C18 $(0.11 \mathrm{mg} / \mathrm{mL}$ dan $0.2 \mathrm{mg} / \mathrm{mL})$. Analisis TLC (butanol: etanol: air = 6: 3: 1 dan 5: 4: 1) menunjukkan kehadiran fOS dalam kedua-dua ekstrak MBIE dan C18 berdasarkan tompok aktif orsinol (tidak aktif-UV). Puncak yang sama hadir dalam kromatogram HPLC-ELSD untuk kedua-dua kaedah pengekstrakan dengan MBIE menunjukkan kelimpahan yang lebih tinggi. Analisis unit glikan (GU) terhadap data HPLC-ELSD piawai dekstran menunjukkan struktur oligosakarida yang paling besar dikesan hanya di/trisakarida. Berdasarkan keputusan yang diperoleh, pengekstrakan MBIE merupakan teknik pengekstrakan karbohidrat yang lebih sesuai berbanding dengan pengekstrakan C18 untuk kajian profil dan fungsi fOS.

Kata kunci: Glikan; HPLC-ELSD; Oligosakarida bebas (fOS); Saccharomyces cerevisiae; TLC 


\section{INTRODUCTION}

$N$-glycosylation is the most diverse form of protein modification in all eukaryotes and some prokaryotes. This process occurs in the endoplasmic reticulum (ER) and is catalysed by the enzyme oligosaccharyltransferase (OST). The membrane-bound enzyme co-translationally transfers the accumulated dolicholpyrophosphate $\mathrm{Glc}_{3} \mathrm{Man}_{9} \mathrm{GlcNAc}_{2}$ oligosaccharide to the asparagine residue in the protein with the sequence $\mathrm{N}-\mathrm{X}-\mathrm{S} / \mathrm{T}(\mathrm{N}=$ asparagine, $\mathrm{X}=$ any amino acid except proline, $\mathrm{S}=$ serine, $\mathrm{T}=$ threonine) to produce $N$-linked glycoproteins (Roth et al. 2010). In ER quality control, the $\mathrm{Glc}_{3} \mathrm{Man}_{9} \mathrm{GlcNAc}_{2}$ form of the donor glycan, linked covalently to nascent proteins, is rapidly trimmed by enzymes glucosidases I and II and, in some cases, ER $\alpha$-mannosidase I, converting it to Glc $\mathrm{Man}_{8} \mathrm{GlcNAc}_{2}$. The glucosylated $N$-linked glycans (oligosaccharides) $\mathrm{Glc}_{1-}$ ${ }_{3} \mathrm{Man}_{9} \mathrm{GlcNAc}_{2}$ involved in this process are important in protein biosynthesis and folding that occurs during endoplasmic reticulum-associated degradation (ERAD) (Chantret et al. 2003). The lectin molecular chaperones, calnexin and calreticulin, are known to interact with the monoglucosylated $N$-glycans in a conformationally dependent manner to promote correct folding of newly synthesized glycoproteins (Hirayama et al. 2010; Mackeen et al. 2009). $N$-glycan free oligosaccharides (fOS) are generated from lipid-linked oligosaccharides (LLO) (Harada et al. 2013) and the release of misfolded $\mathrm{N}$-glycoproteins resulting from the ERAD pathway (Helenius \& Aebi 2004). More recently, misfolded $O$-linked glycoproteins have also been reported as a source of fOS (Hirayama et al. 2019). The glycomic profiles of free oligosaccharides (fOS) derived from misfolded $N$ - and $O$-linked glycoproteins and lipid-linked oligosaccharides are important molecular signatures in various biological processes and serve as a readout of functional properties such as glycosidase inhibition. fos profiles are useful for a diverse range of structural and functional studies such as glycoprotein folding (Hirayama 2018; Shenkman et al. 2018), infant gut bacterial colonisation (Karav et al. 2019), lactation (Liu et al. 2019), bacterial (Nothaft et al. 2010) and viral infections (Miller et al. 2018), cancer (Alonzi et al. 2011), and degenerative diseases such as osteoarthritis (Homan et al. 2019), congenital-defects of glycosylation (CDG) (Davids et al. 2019), and lysosomal storage disorders (Huang et al. 2018). Additionally, fOS accumulation has also been used to evaluate the cell-based inhibition of glycosidase enzymes by small molecules (Glawar et al. 2012; Rawlings et al. 2009).

Several methods of fOS extraction have been reported in the literature such as mixed-bed ion-exchange (MBIE), C18 reversed-phase, hydrophilic interaction chromatography (HILIC) and porous graphite carbon (PGC) (Alonzi et al. 2008; Lin et al. 2014; Verostek et al. 2000; Zhang et al. 2014). Each of these extraction methods may influence the glycan profiles obtained due to their different sorbent chemistries. The valuable information obtained through glycan profiling is important for various applications, for example characterisation of therapeutic glycoproteins
(Higgins 2010). However, very few reports compare the profiles and yields of different glycan/oligosaccharide extraction methods. Therefore, in this study, two commonly used methods of extraction based on different sorbent chemistries namely mixed-bed ion-exchange (MBIE) [AG50W-X12 $\left(\mathrm{H}^{+}\right) / \mathrm{AG} 2-\mathrm{X} 8\left(\mathrm{Cl}^{-}\right)$] by Alonzi et al. (2008) and $\mathrm{C} 18$ reversed-phase by Lin et al. (2014) sorbents were used to compare the fOS profiles extracted from wild-type S. cerevisiae.

The MBIE method has been previously reported by Alonzi et al. (2008) as a simple technique with high recovery $(\sim 90 \%)$. This ion-exchange based method utilises a cation $\left(\mathrm{H}^{+}\right.$counter-ion) over anion $\left(\mathrm{OH}^{-}\right.$counter-ion) resin column. Besides that, the MBIE technique does not require the use of organic solvents and phase separation for glycan extraction employed by Mellor et al. (2004). The reversedphase $\mathrm{C} 18$ method operates on the basis of complementary hydrophobic retention and hydrophilic elution. Complextype of $N$-glycans (sialylated complex-type structures) and high-mannose structures have been extracted using a C18 cartridge (Lin et al. 2014). Both these extraction methods will desalt, deproteinate and extract glycans but may provide different profiles of glycans and protein yields as well as display the presence/absence of different glycans thereby influencing the fOS profiles obtained in this study. Therefore, we report the comparison of fOS profiles extracted from $S$. cerevisiae using MBIE and C18 extractions that were analysed and characterised by TLC (with UV and the carbohydrate-affinity stain orcinol), highperformance liquid-chromatography with an evaporative light scattering detector (HPLC-ELSD) for the universal detection and total content assays (phenol-sulfuric acid for glycans and bicinchoninic acid for proteins).

\section{Materials AND Methods}

\section{MateRIALS}

Wild-type S. cerevisiae (Baker's yeast) was kindly donated by Dr. Farah Diba Abu Bakar from Microbiology Programme, Centre for Biotechnology and Functional Food, Faculty of Science and Technology, UKM. All the reagents used were from Sigma unless specified otherwise: HPLC-grade solvent from JT baker, water was Milli- $\mathrm{Q}^{\mathrm{TM}}$ grade, C18 Sep-Pak cartridge from Supelco and ionexchange resin from Bio-Rad. The column used for the HPLC-ELSD analysis is a XBridge amide HILIC column $(4.6 \times 250 \mathrm{~mm}, 3.5 \mu \mathrm{m}$ particle size $)$ purchased from Waters. A glycan molecular weight ladder standard was prepared from the partial hydrolysis of dextran.

\section{Preparation of DeXtran Molecular WEIGHT LADDER}

The dextran ladder standard was prepared via partial hydrolysis using $100 \mathrm{mg}$ of dextran (MW 200,000) dissolved in $1 \mathrm{~mL}$ of $0.1 \mathrm{M} \mathrm{HCl}$ and heated at $100{ }^{\circ} \mathrm{C}$ for 
$4 \mathrm{~h}$. The reaction was cooled and subsequently passed through a column packed with $2 \mathrm{~mL}$ of Bio-Rad AG3-X4A (OH' form, 100-200 mesh) to deplete excess hydrochloric acid. Then, the eluted sample was diluted with $2 \mathrm{~mL}$ of water. The dextran standard was then kept at $-20{ }^{\circ} \mathrm{C}$ until use for oligosaccharide HPLC analysis.

\section{CULTURE OF WILD-TYPE (WT) SACCHAROMYCES CEREVISIAE AND EXTRACTION OF FREE OLIGOSACCHARIDES (FOS)}

Two sets of $S$. cerevisiae were inoculated into $5 \mathrm{~mL}$ of YPD medium and incubated at $30{ }^{\circ} \mathrm{C}, 240 \mathrm{rpm}$ for $24 \mathrm{~h}$. The growth of the culture was monitored at $\mathrm{OD}_{600}$ till it reaches around 1.0. The overnight culture $\left(\sim 1 \times 10^{7}\right.$ cells $\left./ \mathrm{mL}\right)$ was added into $500 \mathrm{~mL}$ YPD medium and then incubated at 30 ${ }^{\circ} \mathrm{C}, 240 \mathrm{rpm}$ for $48 \mathrm{~h}$. Cell lysis was performed as described previously (Jalaludin et al. 2017). After $48 \mathrm{~h}$, the cell pellets were harvested by centrifugation $\left(2500 \mathrm{rpm}, 4{ }^{\circ} \mathrm{C}\right.$ and $8 \mathrm{~min}$ ) and washed (3X) using phosphate-buffered saline (PBS). Subsequently, the cells were snap-frozen using liquid nitrogen for $10 \mathrm{~s}$ and thawed three times. The cell pellets were resuspended in lysis buffer $(100 \mathrm{mM}$ Tris- $\mathrm{HCl}$, pH7.4 containing $4 \mathrm{mM} \mathrm{MgCl}_{2}$ ) and acid-washed glass beads and subsequently vortexed for $30 \mathrm{~s}$ (six times). The cell debris was then removed by centrifugation (4300 rpm, $4^{\circ} \mathrm{C}$ and $5 \mathrm{~min}$ ) and supernatant ( 2 sets) were collected for fOS extraction. Free oligosaccharide extraction was performed using two previously reported methods; MBIE [AG50W-X12 $\left(\mathrm{H}^{+}\right) / \mathrm{AG} 2-\mathrm{X} 8\left(\mathrm{Cl}^{-}\right)$] by Alonzi et al. (2008) and $\mathrm{C} 18$ reverse-phase cartridge by Lin et al. (2014). In the first method, supernatant (1 set) was applied onto a mixed-bed ion-exchange column [0.2 mL of AG50W-X12 $\left(\mathrm{H}^{+}, 100-200 \mathrm{mesh}\right)$ over $0.4 \mathrm{~mL}$ of AG3-X4 $\left(\mathrm{OH}^{-}, 100-200\right.$ mesh)], pre-equilibrated with water $(5 \times 1 \mathrm{~mL})$ then washed with $4 \times 1 \mathrm{~mL}$ of water. The eluate was collected for further analysis. In the second method, the supernatant (1 set) was loaded onto $\mathrm{C} 18$ cartridge that were equilibrated with 5.0 $\mathrm{mL}$ of acetonitrile $(50 \%), 5.0 \mathrm{~mL}$ of acetonitrile $(25 \%)$ and $10 \mathrm{~mL}$ formic acid $(0.1 \%)$. The fOS was eluted with $3 \mathrm{~mL}$ of $5 \%$ acetonitrile $/ 0.1 \%$ formic acid. Aliquots from both extraction methods were collected (before and after extraction) for the bicinchoninic acid (BCA) and phenolsulfuric acid (PSA) assays.

\section{BICINCHONINIC ACID ASSAY (BCA) FOR PROTEIN} QUANTIFICATION

Protein concentration was determined using the bicinchoninic acid (BCA) assay as described previously (Schoel et al. 1995). The working reagent was prepared by adding and mixing $\mathrm{CuSO}_{4} \cdot 5 \mathrm{H}_{2} \mathrm{O}(1 \%)$ to $\mathrm{BCA}$ at the ratio of $1: 40$ and was filtered using a $0.45 \mu \mathrm{m}$ polytetrafluoroethylene (PTFE) membrane prior to use. Bovine serum albumin (BSA) was used as the standard to prepare a standard curve with concentration of BSA ranging between 0.2 and $1.0 \mathrm{mg} / \mathrm{mL}$. BSA $(20 \mu \mathrm{L})$ was first added into the microplate well and followed by $200 \mu \mathrm{L}$ of the working reagent. Samples were then incubated at $60{ }^{\circ} \mathrm{C}$ for $15 \mathrm{~min}$. Protein concentration was measured by reading the absorbance at $595 \mathrm{~nm}$ using a microplate reader (BioRad model 680). A standard curve of absorbance $\left(\mathrm{A}_{595 \mathrm{~nm}}\right)$ vs concentration $(\mathrm{mg} / \mathrm{mL})$ was plotted. Each calibration point was carried out in triplicate and the linearity (coefficient of determination, $\mathrm{R}^{2}$ ) of the calibration curve was determined. For the cell lysate and fOS extracts, samples were diluted five times and the protein concentration was determined. All assay reactions were performed in triplicate.

\section{PHENOL-SULFURIC ACID ASSAY FOR OLIGOSACCHARIDE}

\section{QUANTIFICATION}

The concentration of oligosaccharides in the extracted fOS samples were determined using the phenol sulfuric acid assay (PSA) as described previously (Jalaludin et al. 2017; Masuko et al. 2005). Quantification of foS was carried out using a calibration curve generated using glucose as a standard. The standard calibration curve was plotted by using a series of known glucose standard concentrations $(0.1,0.2,0.3,0.4$ and $0.5 \mathrm{mg} / \mathrm{mL})$ prepared by serial dilution. Glucose $(200 \mu \mathrm{L})$ was added to $200 \mu \mathrm{L}$ of phenol $(5 \%)$ and $1 \mathrm{~mL}$ of concentrated sulfuric acid. The mixture was vortexed and incubated at $100{ }^{\circ} \mathrm{C}$ for $10 \mathrm{~min}$. After incubation, samples were diluted five times and absorbance (UV-Vis) was measured at $490 \mathrm{~nm}\left(\mathrm{~A}_{490 \mathrm{~nm}}\right)$ using a spectrophotometer. All assay reactions were performed in triplicate.

\section{THIN LAYER CHROMATOGRAPHY (TLC)}

Analytical thin layer chromatography (TLC) was carried out on aluminium sheets coated with 60 F254 silica purchased from Merck. The samples from both extraction methods (before and after extraction) were spotted on TLC plate and developed using a solvent system comprised of butanol: ethanol: water at two different ratios (6:3:1 and 5:4:1). The TLC plates were observed under UV at wavelength $254 \mathrm{~nm}$ and then, the TLC plate was stained with orcinol followed by heating for $2 \mathrm{~min}$ (till spots were observed). The staining solution was prepared by dissolving $0.2 \mathrm{mg}$ of orcinol in $1.1 \mathrm{~mL}$ of concentrated sulfuric acid and $10 \mathrm{~mL}$ of water.

\section{HIGH-PERFORMANCE LIQUID CHROMATOGRAPHY-} EVAPORATIVE LIGHT SCATTERING DETECTOR (HPLC-ELSD)

The partially hydrolysed dextran standard, glucose standard and fOS of $S$. cerevisiae extracts were analysed using a Dionex HPLC instrument coupled to an evaporative light scattering detector (HPLC-ELSD). Samples were separated on a XBridge Amide column $(4.6 \times 250 \mathrm{~mm}, 3.5 \mu \mathrm{m}$ particle size) (Waters Corporation, MA, USA) with slight modifications (Jalaludin et al. 2017) to the method previously reported by Neville et al. (2004). The mobile phases comprised of solvent A containing $80 \%(\mathrm{v} / \mathrm{v})$ 
acetonitrile and 20\% (w/v) $100 \mathrm{mM}$ ammonium acetate (pH6.0) while solvent B containing 20\% (v/v) acetonitrile and $20 \%(\mathrm{w} / \mathrm{v}) 100 \mathrm{mM}$ ammonium acetate (pH6.0) and $60 \%(\mathrm{v} / \mathrm{v})$ MilliQ- $\mathrm{H}_{2} \mathrm{O}$. The following gradient conditions were used for the HPLC-ELSD analysis: time $0 \mathrm{~min}(\mathrm{t}-0)$, $86 \%$ A, $14 \%$ B (0.8 mL/min); t-6, 86\% A, $14 \%$ B (0.8 mL/ $\min )$; $-40,47.6 \%$ A, $53.4 \%$ B (0.8 mL/min); t- 42, 5\% A, 95\% B (0.8 mL/min); t-44, 5\% A, 95\% B (0.8 mL/min); $\mathrm{t}-46,86 \%$ A, $14 \%$ B (0.8 mL/min); t- $47,86 \%$ A, $14 \%$ B (0.8 mL/min), t-59, 86\% A, $14 \%$ B $(0.8 \mathrm{~mL} / \mathrm{min})$; and $\mathrm{t}-60,86 \% \mathrm{~A}, 14 \% \mathrm{~B}(0.8 \mathrm{~mL} / \mathrm{min})$. The injection volume of sample for MBIE extraction method was $10 \mu \mathrm{L}$ and for the $\mathrm{C} 18$ reversed-phase cartridge was $60 \mu \mathrm{L}$.

\section{ReSUlts AND Discussion}

\section{TOTAL CONCENTRATION OF CARBOHYDRATES (PSA ASSAY) AND PROTEINS (BCA ASSAY)}

The total concentration of carbohydrates was determined using the PSA assay. A standard curve for quantification was generated using glucose and the linear equation, $\mathrm{y}$
$=3.236 \mathrm{x}\left(\mathrm{R}^{2}=0.993\right)$ generated from the standard curve was used to quantify the carbohydrate content (Figure 1). Comparison between the fOS crude extracts using MBIE and C18 reversed-phase methods showed that the concentration of total carbohydrates was higher in the MBIE extract $(0.26 \mathrm{mg} / \mathrm{mL})$ than the $\mathrm{C} 18$ extract $(0.11$ $\mathrm{mg} / \mathrm{mL})$. On the other hand, the total protein content was determined using BCA assay. The standard curve generated using BSA as standard resulted in a linear equation of $y=0.4145 x\left(R^{2}=0.959\right)$ as shown in Figure 2. The BCA standard curve was used to determine the protein concentration in fOS extracts. Initially, the protein concentration of the $S$. cerevisiae cell lysate was determined before fOS extraction to ensure the efficiency of the extraction methods. The initial total protein concentration of cell lysate obtained based on the standard curve was $3.5 \mathrm{mg} / \mathrm{mL}$. The protein concentration after fOS extraction showed that MBIE extracts $(1.8 \mathrm{mg} /$ $\mathrm{mL}$ ) had higher protein content compared to the C18 extracts $(0.2 \mathrm{mg} / \mathrm{mL})$. As summarised in Table 1 , the concentrations of proteins and oligosaccharides were 9-fold and 2.4-fold higher in the MBIE extract than C18 extract, respectively.

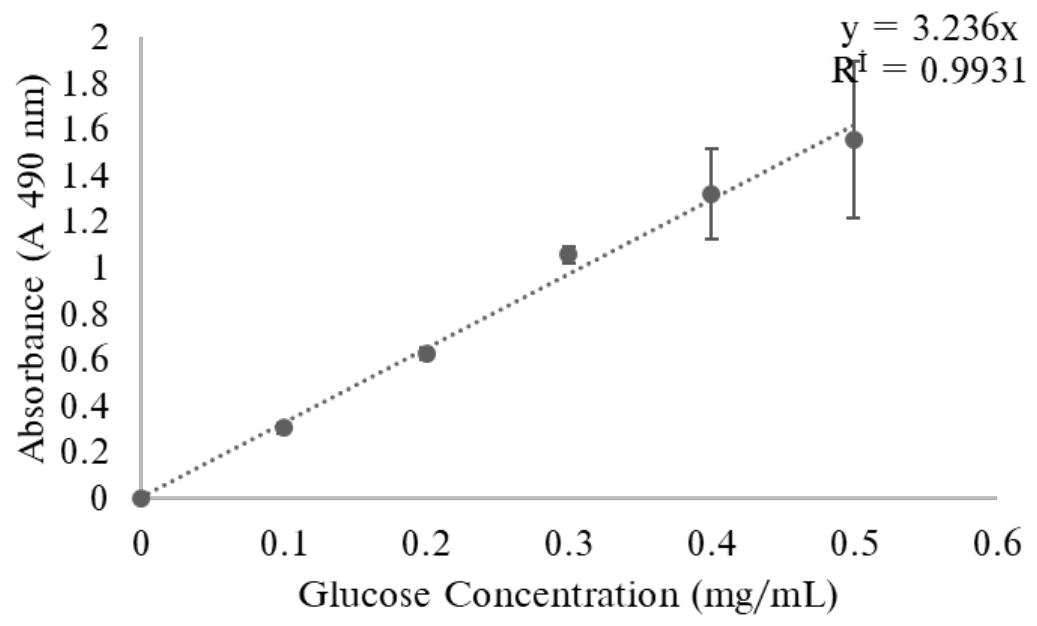

FIGURE 1. Standard curve of carbohydrate concentration (glucose standard) for the PSA assay

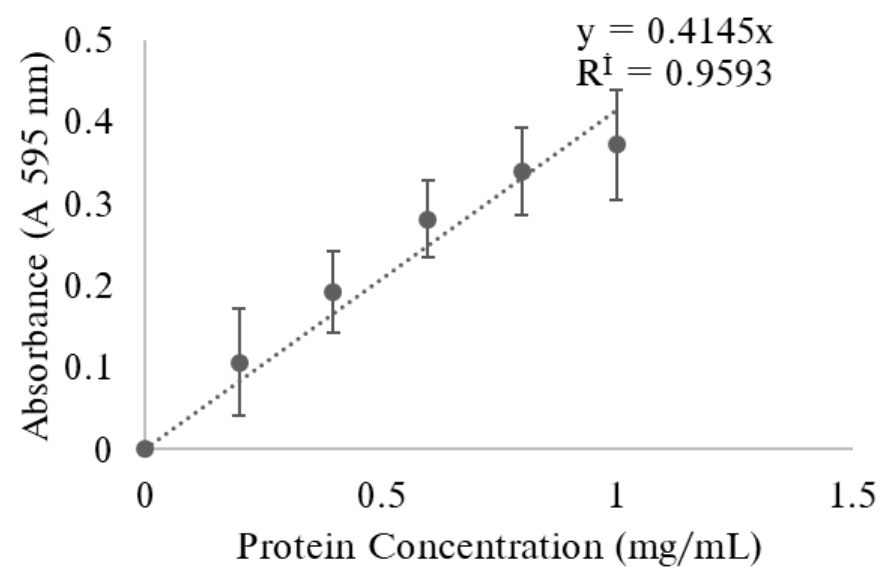

FIGURE 2. Standard curve of protein concentration (BSA standard) for the BCA assay 
TABLE 1. Carbohydrate and protein concentration of fOS extract

\begin{tabular}{lcccc}
\hline \multirow{2}{*}{ Extraction method } & \multicolumn{2}{c}{ Concentration $(\mathrm{mg} / \mathrm{mL})$} & \multicolumn{2}{c}{ Percentage $(\%)$} \\
& Carbohydrate & Protein & Carbohydrate & Protein \\
\hline MBIE & 0.26 & 1.8 & 5.2 & 36 \\
C18 reversed- phase & 0.11 & 0.2 & 2.2 & 4 \\
\hline
\end{tabular}

SEPARATION PROFILE OF FOS EXTRACTS USING TLC AND HPLC-ELSD

The separation profile of fOS extracts from MBIE and C18 methods were analysed using two chromatography techniques which are thin layer chromatography (TLC) and high-performance liquid chromatography-evaporative light scattering detector (HPLC-ELSD). ELSD is a universal detector which detects both carbohydrate and noncarbohydrate compounds, and TLC is used for selective detection of oligosaccharides using affinity stains such as orcinol further complemented with the absence of UV spots due to the lack of chromophores in glycans. The TLC analysis optimised using a solvent system (butanol: ethanol: water) at two different ratios (6:3:1 and 5:4:1) showed similar separation profiles for both MBIE and C18 extracts (Figure 3). Under UV light, several spots were detected with low and high $\mathrm{R}_{\mathrm{f}}$ values, suggesting the presence of either non-carbohydrate or carbohydrate-

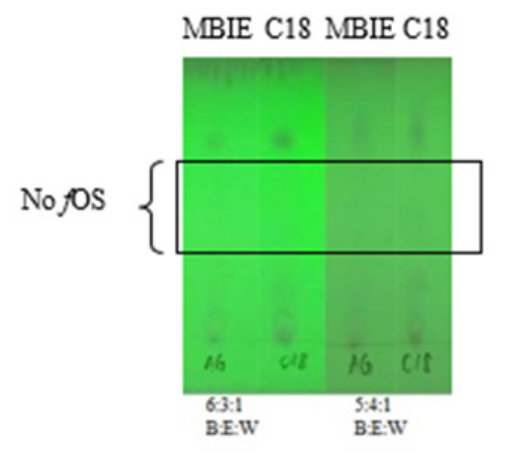

(a)

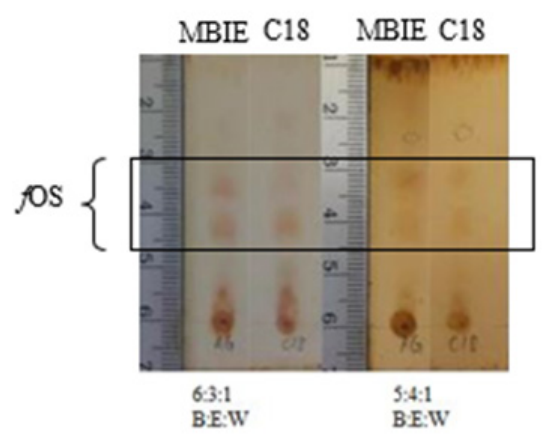

(b)

FIGURE 3. TLC plates of mixed-bed ion-exchange (MBIE) and C18 fOS extracts viewed (a) under UV and (b) after orcinol stainin
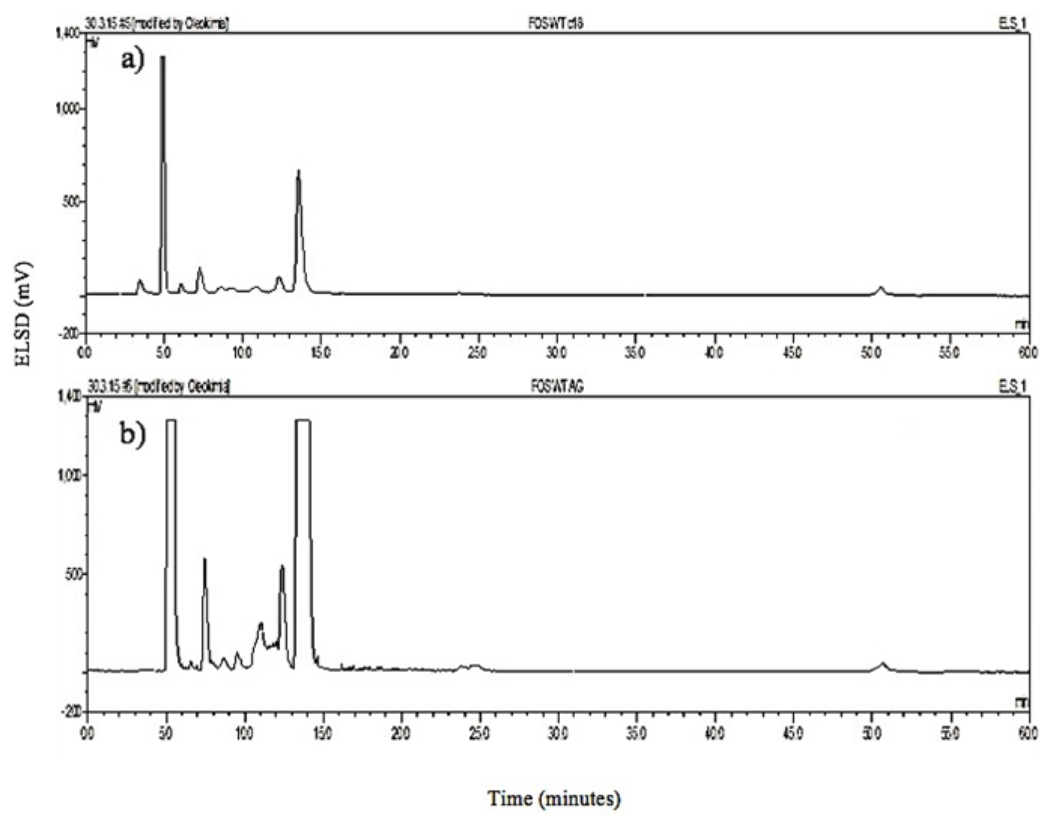

FIGURE 4. HPLC-ELSD chromatograms (0-60 min) of: a) C18 (reversed-phase) extraction (6-fold higher concentration than MBIE) and b) MBIE extraction 

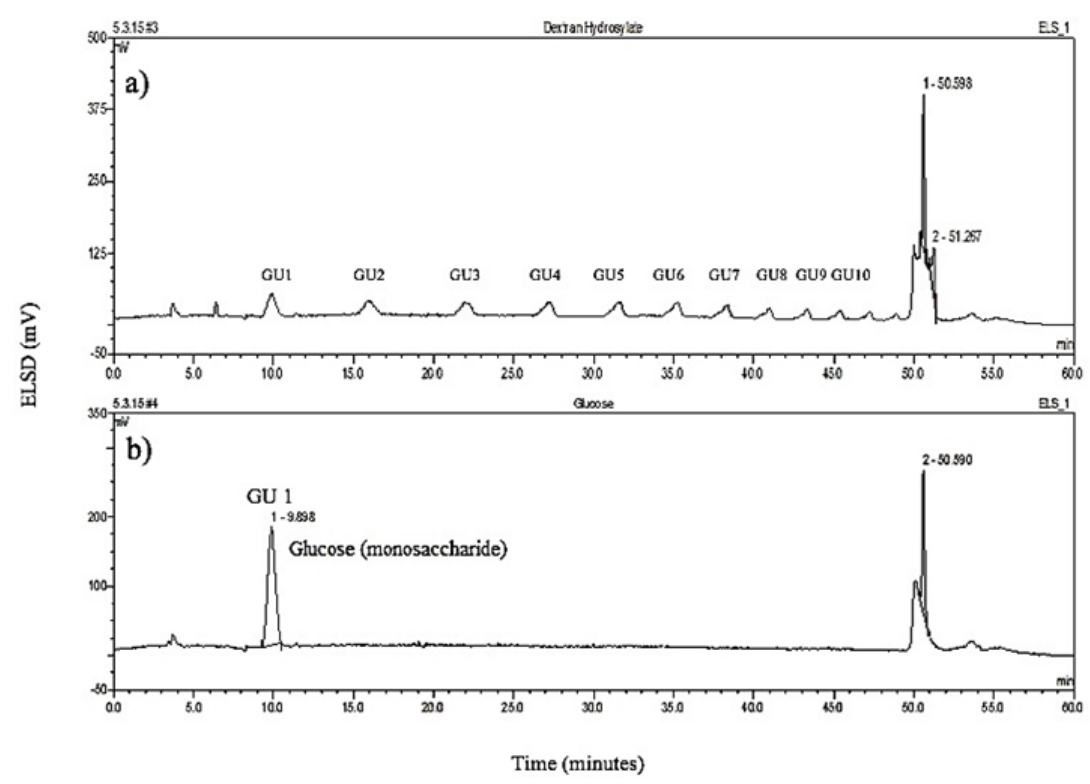

FIGURE 5. HPLC-ELSD chromatograms (0-60 min) of: a) partially hydrolysed dextran standard and b) glucose standard

conjugated metabolites (Figure 3(a)). However, when the TLC plates were stained with orcinol, a carbohydrate affinity stain, spots with mid-range $\mathrm{R}_{\mathrm{f}}$ values were observed for both MBIE and C18 extracts (Figure 3(b)). This suggests the presence of unbound carbohydrates (fOS) in both samples. The intensity of foS spots observed to be stronger in the MBIE extract than the C18 extract and this is consistent with the PSA results which showed higher total carbohydrate content in MBIE than C18 extract.

Profiling of the fOS extracts by HPLC using the universal detector ELSD showed similar peaks for both extraction methods (Figure 4). However, the intensities of all peaks were much higher in the MBIE extract than the $\mathrm{C} 18$ extract. The dominant peaks at retention times $\mathrm{R}_{\mathrm{t}} 5.2$ and $14.8 \mathrm{~min}$ were particularly high in the MBIE extract. These peaks may correspond to protein-related material in the samples with 9-fold higher concentration of proteins in the MBIE extract than the $\mathrm{C} 18$ extract determined using the BCA assay. The fOS detected using TLC may correspond to the smaller peaks in between the two dominant peaks observed in the chromatogram. The HPLC-ELSD results also showed that higher order $N$-glycan structures were not detected in both extracts which would appear at much higher $R_{t}$ values. The $R_{t}$ values of the peaks detected showed that any possible glycan peaks would be the smaller structures of mono- to di-saccharides determined based on glycan unit (GU) analysis of a dextran ladder (Figure 5). This may be due to very low abundance of high-mannose glycans and the truncation of these structures by mannosidases to more abundant smaller structures.

\section{Conclusion}

Free oligosaccharide extraction (foS) from $S$. cerevisiae using mixed-bed ion-exchange (MBIE) resulted in higher carbohydrate and protein content compared to the $\mathrm{C} 18$ reversed-phase extract. The high protein content from MBIE extraction makes it less suitable for de-proteination. HPLCELSD results also showed that larger glycans ( $>$ di/trisaccharides) were not detected most probably due to truncation by enzymes and low abundance. Therefore, all these results suggested that while mixed-bed ion-exchange extraction was a more suitable method of carbohydrate extraction, it also yielded a much higher quantity of proteins compared to $\mathrm{C} 18$ extraction. Further studies should be carried out to further optimise MBIE extraction to reduce protein content and also evaluate other common fOS extraction techniques to increase the carbohydrate over protein ratio for subsequent profiling and functional studies of fOS.

\section{ACKNOWLEDGEMENTS}

This work was supported by the Ministry of Higher Education, Malaysia under Grant ERGS/1/2013/STG01/ UKM/01/1 and the Malaysia Genome Institute, Ministry of Science, Technology and Innovation Malaysia (MOSTI) under grant 02- 05-20- SF0007. The authors also wish to thank Tan Sur Chong for her assistance with some of the experiments and the Department of Chemical Sciences, Department of Biosciences and Biotechnology, Institute of Systems Biology, Universiti Kebangsaan Malaysia, and the Oxford Glycobiology Institute, University of Oxford for access to their facilities and technical support.

\section{REFERENCES}

Alonzi, D.S., Su, Y.H. \& Butters, T.D. 2011. Urinary glycan markers for disease. Biochemical Society Transactions 39: 393-398.

Alonzi, D.S., Neville, D.C.A., Lachmann, R.H., Dwek, R.A. \& Butters, T.D. 2008. Glucosylated free oligosaccharides are 
biomarkers of endoplasmic-reticulum alpha-glucosidase inhibition. Biochemical Journal 409: 571-580.

Chantret, I., Frenoy, J.P. \& Moore, S.E.H. 2003. Freeoligosaccharide control in the yeast Saccharomyces cerevisiae: Roles for peptide: N-glycanase (Png1p) and vacuolar mannosidase (Ams1p). Biochemical Journal 373: 901-908.

Davids, M., Kane, M.S., Wolfe, L.A., Toro, C., Tifft, C.J., Adams, D., Li, X., Raihan, M.A., He, M., Gahl, W.A., Boerkoel, C.F. \& Malicdan, M.C.V. 2019. Glycomics in rare diseases: From diagnosis to mechanism. Translational Research 206: 5-17.

Glawar, A.F.G., Best, D., Ayers, B.J., Miyauchi, S., Nakagawa, S., Aguilar-Moncayo, M., García Fernández, J.M., Ortiz Mellet, C., Crabtree, E.V., Butters, T.D., Wilson, F.X., Kato, A. \& Fleet, G.W.J. 2012. Scalable syntheses of both enantiomers of DNJNAc and DGJNAc from glucuronolactone: The effect of $N$-alkylation on hexosaminidase inhibition. Chemistry European Journal 18: 9341-9359.

Harada, Y., Buser, R., Ngwa, E.M., Hirayama, H., Aebi, M. \& Suzuki, T. 2013. Eukaryotic oligosaccharyltransferase generates free oligosaccharides during $\mathrm{N}$-glycosylation. Journal Biological Chemistry 288: 32673-32684.

Higgins, E. 2010. Carbohydrate analysis throughout the development of a protein therapeutic. Glycoconjugate Journal 21: 211-225.

Helenius, A. \& Aebi, M. 2004. Roles of $N$-linked glycans in the endoplasmic reticulum. Annual Review of Biochemistry 73: 1019-1049.

Hirayama, H. 2018. Biology of free oligosaccharides: Function and metabolism of free $\mathrm{N}$-glycans in eukaryote. Trends in Glycoscience and Glycotechnology 30: E161-E167.

Hirayama, H., Matsuda, T., Tsuchiya, Y., Oka, R., Seino, J., Huang, C., Nakajima, K., Noda, Y., Scichino, Y., Iwasaki, S. \& Suzuki, T. 2019. Free glycans derived from $O$-mannosylated glycoproteins suggest the presence of an $O$-glycoprotein degradation pathway in yeast. Journal of Biological Chemistry 294(44): 15900-15911.

Hirayama, H., Seino, J., Kitajima, T., Jigami, Y. \& Suzuki, T. 2010. Free oligosaccharides to monitor glycoprotein endoplasmic reticulum-associated degradation in Saccharomyces cerevisiae. Journal of Biological Chemistry 285: 12390-12404.

Homan, K., Hanamatsu, H., Furukawa, J.I., Okada, K., Yokota, I., Onodera, T. \& Iwasaki, N. 2019. Alteration of the total cellular glycome during late differentiation of chondrocytes. International Journal of Molecular Sciences 20: 1-16.

Huang, R., Cathey, S., Pollard, L. \& Wood, T. 2018. UPLC-MS/ MS analysis of urinary free oligosaccharides for lysosomal storage diseases: Diagnosis and potential treatment monitoring. Clinical Chemistry 64: 1772-1779.

Jalaludin, I., Sudin, A.H., Said, I.H., Azizan, K.A., Baharum, S.N., Murad, A.M.A., Bakar, F.D.B., Mahadi, N.M., Wormald, M.R., Alonzi, D.S. \& Mackeen, M.M. 2017. Fluorescence and evaporative light scattering HPLC profiling of intracellular asparagine (N)-linked oligosaccharides from Saccharomyces cerevisiae using the Alg8 mutant. Malaysian Journal of Analytical Sciences 21: 1210-1218.

Karav, S., Casaburi, G., Arslan, A., Kaplan, M., Sucu, B. \& Frese, S. 2019. $\mathrm{N}$-glycans from human milk glycoproteins are selectively released by an infant gut symbiont in vivo. Journal of Functional Foods 61: 1-6.
Lin, C.H., Kuo, C.W., Jarvis, D.L. \& Khoo, K.H. 2014. Facile removal of high mannose structures prior to extracting complex type $\mathrm{N}$-glycans from de- $\mathrm{N}$-glycosylated peptides retained by $\mathrm{C} 18$ solid phase to allow more efficient glycomic mapping. Proteomics 14: 87-92.

Liu, J., Jia, Y., Yang, Y., Chen, Q., Sun, L., Song, S., Huang, L. \& Wang, Z. 2019. Mass spectrometry analysis of changes in human milk $N / O$-glycopatterns at different lactation stages. Journal of Agricultural and Food Chemistry 67: 10702-10712.

Mackeen, M.M., Almond, A., Deschamps, M., Cumpstey, I., Fairbanks, A.J., Tsang, C., Rudd, P.M., Butters, T.D., Dwek, R.A. \& Wormald, M.R. 2009. The conformational properties of the $\mathrm{Glc}_{3}$ Man unit suggest conformational biasing within the chaperone-assisted glycoprotein folding pathway. Journal of Molecular Biology 387: 335347.

Masuko, T., Minami, A., Iwasaki, N., Majima, T., Nishimura, S.I. \& Lee, Y.C. 2005. Carbohydrate analysis by a phenolsulfuric acid method in microplate format. Analytical Biochemistry 339: 69-72.

Mellor, H., Neville, D.C.A., Harvey, D.J., Platt, F.M., Dwek, R.A. \& Butter, T.D. 2004. Cellular effects of deoxynojirimycin analogues: Inhibition of $N$-linked oligosaccharide processing and generation of free glucosylated oligosaccharides. Biochemical Journal 381: 867-875.

Miller, J.L., Tyrrell, B.E. \& Zitzmann, N. 2018. Mechanisms of antiviral activity of iminosugars against dengue virus. Advances in Experimental Medicine and Biology 1062: 277-301.

Neville, D.C.A., Coquard, V., Priestman, D.A., te Vruchte, D.J.M., Sillence, D.J., Dwek, R.A., Platt, F.M. \& Butters, T.D. 2004. Analysis of fluorescently labelled glycosphingolipid-derived oligosaccharides following ceramide glycanase digestion and anthranilic acid labeling. Analytical Biochemistry 331: 275-282.

Nothaft, H., Liu, X., Li, J. \& Szymanski, C.M. 2010. Campylobacter jejuni free oligosaccharides function and fate. Virulence 1: 546-550.

Rawlings, A.J., Lomas, H., Pilling, A.W., Lee, M.J.R., Alonzi, D.S., Rountree, J.S.S., Jenkinson, S.F., Fleet, G.W.J., Dwek, R.A., Jones, J.H. \& Butters, T.D. 2009. Synthesis and biological characterisation of novel $N$-alkyldeoxynojirimycin glucosidase inhibitors. ChemBioChem 10: 1101-1105.

Roth, J., Zuber, C., Park, S., Jang, I., Lee, Y., Kysela, K.G., Forum, V.L., Santimaria, R., Guhl, B. \& Cho, J.W. 2010. Protein $\mathrm{N}$-glycosylation, protein folding, and protein quality control. Molecules and Cells 30: 497-506.

Schoel, B., Welzel, M. \& Kaufmann, S.H.E. 1995. Quantification of protein in dilute and complex samples: Modification of the bicinchoninic acid assay. Journal of Biochemical and Biophysical Methods 30: 199-206.

Shenkman, M., Ron, E., Yehuda, R., Benyair, R., Khalaila, I. \& Lederkremer, G.Z. 2018. Mannosidase activity of EDEM1 and EDEM2 depends on an unfolded state of their glycoprotein substrates. Communications Biology 1: 1-11.

Verostek, M.F., Lubowski, C. \& Trimble, R.B. 2000. Selective organic precipitation/extraction of released $\mathrm{N}$-glycans following large-scale enzymatic deglycosylation of glycoproteins. Analytical Biochemistry 278: 111-122.

Zhang, Q., Li, H., Feng, X., Liu, B.F. \& Liu, X. 2014. Purification of derivatised oligosaccharides by solid phase extraction for glycomic analysis. PLoS ONE 9: 1-10. 
Iqbal Jalaludin, Amirul Husna Sudin, Dharshini Elangovan, Hussein M. Al-Bajalan \& Mukram Mohamad Mackeen*

Department of Chemical Sciences

Faculty of Science and Technology

Universiti Kebangsaan Malaysia

43600 UKM Bangi, Selangor Darul Ehsan

Malaysia

Nur Maisarah Sarizan, Kamalrul Azlan Azizan \& Mukram Mohamad Mackeen*

Institute of Systems Biology

Universiti Kebangsaan Malaysia

43600 UKM Bangi, Selangor Darul Ehsan

Malaysia
Noor Liana Mat Yajit, Abdul Munir Abdul Murad \& Farah Diba Abu Bakar

Department of Biosciences and Biotechnology

Faculty of Science and Technology

Universiti Kebangsaan Malaysia

43600 UKM Bangi, Selangor Darul Ehsan

Malaysia

Dominic S. Alonzi

Oxford Glycobiology Institute

University of Oxford

Oxford OX1 3QU

United Kingdom

*Corresponding author; email: mukram.mackeen@ukm.edu. my

Received: 1 October 2019

Accepted: 22 October 2019 